University of Nebraska - Lincoln

DigitalCommons@University of Nebraska - Lincoln

Faculty Publications from the Harold W. Manter Laboratory of Parasitology

2000

\title{
Life Cycle of Calyptospora funduli (Apicomplexa:
}

Calyptosporidae)

\author{
John W. Fournie \\ United States Environmental Protection Agency \\ Wolfgang K. Vogelbein \\ Virginia Institute of Marin eScience, wolf@vims.edu \\ Robin M. Overstreet \\ Gulf Coast Research Laboratory, robin.overstreet@usm.edu \\ William E. Hawkins \\ Gulf Coast Research Laboratory
}

Follow this and additional works at: https://digitalcommons.unl.edu/parasitologyfacpubs

Part of the Parasitology Commons

\begin{abstract}
Fournie, John W.; Vogelbein, Wolfgang K.; Overstreet, Robin M.; and Hawkins, William E., "Life Cycle of Calyptospora funduli (Apicomplexa: Calyptosporidae)" (2000). Faculty Publications from the Harold W. Manter Laboratory of Parasitology. 406.

https://digitalcommons.unl.edu/parasitologyfacpubs/406
\end{abstract}

This Article is brought to you for free and open access by the Parasitology, Harold W. Manter Laboratory of at DigitalCommons@University of Nebraska - Lincoln. It has been accepted for inclusion in Faculty Publications from the Harold W. Manter Laboratory of Parasitology by an authorized administrator of DigitalCommons@University of Nebraska - Lincoln. 


\title{
LIFE CYCLE OF CALYPTOSPORA FUNDULI (APICOMPLEXA: CALYPTOSPORIDAE)
}

\author{
John W. Fournie, Wolfgang K. Vogelbein ${ }^{\star}$, Robin M. Overstreet $\dagger$, and William E. Hawkins $\dagger$ \\ U.S. Environmental Protection Agency, National Health and Environmental Effects Research Laboratory, Gulf Ecology Division, 1 Sabine Island \\ Drive, Gulf Breeze, Florida 32561
}

\begin{abstract}
The taxonomic status of the extraintestinal piscine coccidium Calyptospora funduli is based in part on its requirement of an intermediate host (the daggerblade grass shrimp Palaemonetes pugio). In the present study, grass shrimp fed livers of Gulf killifish (Fundulus grandis) infected with sporulated oocysts of $C$. funduli exhibited numerous sporozoites suspended in the intestinal contents when fresh squash preparations were examined by light microscopy. Using this method, sporozoites were not seen in intestinal epithelial cells of the grass shrimp or in any other cell types. Ultrastructural examination, however, revealed sporozoites in the cytoplasm of the gut basal cells. Cross-sections of 1-13 sporozoites were seen within a single cell, and those sporozoites each appeared to be situated in individual membrane-bound vesicles, rather than in a single parasitophorous vacuole. These ultrastructural observations indicate that in the grass shrimp intermediate host, sporozoites that develop into an infective stage probably undergo that development in gut mucosal basal cells. Prior studies revealed that these sporozoites modified their structure over 4-5 days and that before that time, they were not infective to the fish host. Following ingestion of an infected shrimp by a killifish, the infective sporozoites apparently reach the liver of their killifish definitive hosts through the bloodstream. Sporozoites were seen in blood smears from the longnose killifish, Fundulus similis, $4 \mathrm{hr}$ after fish were fed experimentally infected grass shrimp. Additionally, coccidian trophozoites and early meronts were seen in hepatocytes from several longnose killifish at 48,72 , and $96 \mathrm{hr}$ postinfection. This study, in conjunction with previous findings, clearly confirms that a true intermediate host is required in the life cycle of $C$. funduli, that a developmental period of about 5 days in grass shrimp is necessary for sporozoites to become infective to killifishes, and that sporozoites do occur intracellularly in gut basal cells of the grass shrimp.
\end{abstract}

Calyptospora funduli is an apicomplexan parasite that infects a variety of atheriniform fishes along the Gulf and east coasts of North America and requires an intermediate host to complete its life cycle (Fournie and Overstreet, 1993). Natural definitive hosts are members of the Cyprinodontidae and Atherinidae and include Fundulus grandis, $F$. similis, $F$. pulvereus, $F$. heteroclitus, $F$. jenkinsi, $F$. confluentus, and Menidia beryllina (Fournie and Overstreet, 1993). The role of an invertebrate intermediate host in the transmission of fish coccidia was first suggested by Landau et al. (1975), demonstrated for $C$. funduli by Solangi and Overstreet (1980), and postulated for some species of Goussia by Overstreet (1981) and Paterson and Desser (1982). However, the first heteroxenous life cycle to be fully demonstrated experimentally for fish coccidia was that of $C$. funduli in killifish (Fournie and Overstreet, 1983). They showed that excysted sporozoites in the intestine of palaemonid shrimps changed morphologically before they became infective to fishes; however, at the light microscopic level, sporozoites were not seen in host cells. Subsequently, Steinhagen and Körting (1990) confirmed that tubificid oligochaetes could serve at least as a paratenic host or vector for Goussia carpelli, and that the sporozoites were located in the cytoplasm of the intestinal epithelial cells of the oligochaete. However, Steinhagen and Körting (1988) previously showed that the oligochaete was not necessary for transmission and that direct infections could occur by fecal contamination from fish to fish.

We report here details regarding the life cycle of $C$. funduli in its intermediate host and clarify the taxonomic status of this coccidium. Specific information is provided regarding intracellular residence of sporozoites in the alimentary tract of the grass

Received 19 August 1999; revised 3 November 1999; accepted 3 November 1999.

* Department of Environmental Sciences, School of Marine Science, Virginia Institute of Marine Science, The College of William and Mary, Gloucester Point, Virginia 23062.

† Gulf Coast Research Laboratory, The University of Southern Mississippi, Ocean Springs, Mississippi 39564. shrimp intermediate host and the route by which these infective sporozoites reach the liver of the killifish definitive host.

\section{MATERIALS AND METHODS}

Materials for this study consisted of livers infected with sporulated oocysts of Calyptospora funduli from the Gulf killifish ( $F$. grandis) caught in minnow traps from Halstead Bayou, Ocean Springs, Mississippi. Daggerblade grass shrimp (Palaemonetes pugio) to be used for feeding studies were caught by dipnet from the same locality. Adult fish (>80 mm total length) to be used for feeding studies were uninfected longnose killifish $(F$. similis) caught by minnow traps from Horn Island, Mississippi. These fish and shrimp were maintained in separate 75-L glass aquaria with $12-15$ ppt salt (Instant Ocean ${ }^{\circledR}$ ) at approximately $23 \mathrm{C}$. Both were fed daily with a varied diet, including frozen brine shrimp, TetraMin ${ }^{\circledR}$, and Kordon Maintenance Flakes ${ }^{\circledR}$.

To determine where in the shrimp alimentary tract the sporozoites reside, grass shrimp were experimentally infected by feeding them liver containing large numbers of sporulated oocysts from wild specimens of $F$. grandis once a day for 3 days. Shrimp were not examined for natural infections prior to feeding with infected fish livers. The intestines were then dissected from the shrimp after 7 days and either examined by light microscopy as fresh squash preparations or processed for electron microscopy.

Grass shrimp intestines for electron microscopy were fixed for $2 \mathrm{hr}$ in 3\% ( $/ / \mathrm{v})$ glutaraldehyde in $0.1 \mathrm{M}$ sodium cacodylate buffer $(\mathrm{pH} 7.4)$, rinsed in $0.1 \mathrm{M}$ sodium cacodylate buffer ( $\mathrm{pH} 7.4$ ), postfixed in cacodylate-buffered $1 \%(\mathrm{wt} / \mathrm{v})$ osmium tetroxide for $2 \mathrm{hr}$, rinsed briefly in buffer, and dehydrated in a graded series of ethanol. Tissues were embedded in Spurr's low viscosity resin. Semithin sections $(1 \mu \mathrm{m})$ were cut using a Reichert Ultracut $\mathrm{E}$ microtome and stained with toluidine blue. Ultrathin sections $(50-60 \mathrm{~nm})$ were cut with a diamond knife, mounted on uncoated copper grids, stained with uranyl acetate and lead citrate (Hayat, 1981), and examined with a Zeiss EM 902A transmission electron microscope.

To determine the route by which sporozoites of $C$. funduli reached hepatocytes, 20 uninfected wild specimens of $F$. similis were fed experimentally infected grass shrimp, and 2 individuals each were examined at $4,8,12,18,24,36,48,72$, and 96 hr postinfection (PI). Before these fish were used as test subjects, livers from 20 were examined by squash preparations and found to be free of infection. Examinations of fish administered infected shrimp involved preparations of peripheral blood smears, tissue impressions of liver and spleen, and histologic sections of liver and intestine. Blood smears were prepared using blood collected from the dorsal aorta after removal of the caudal 


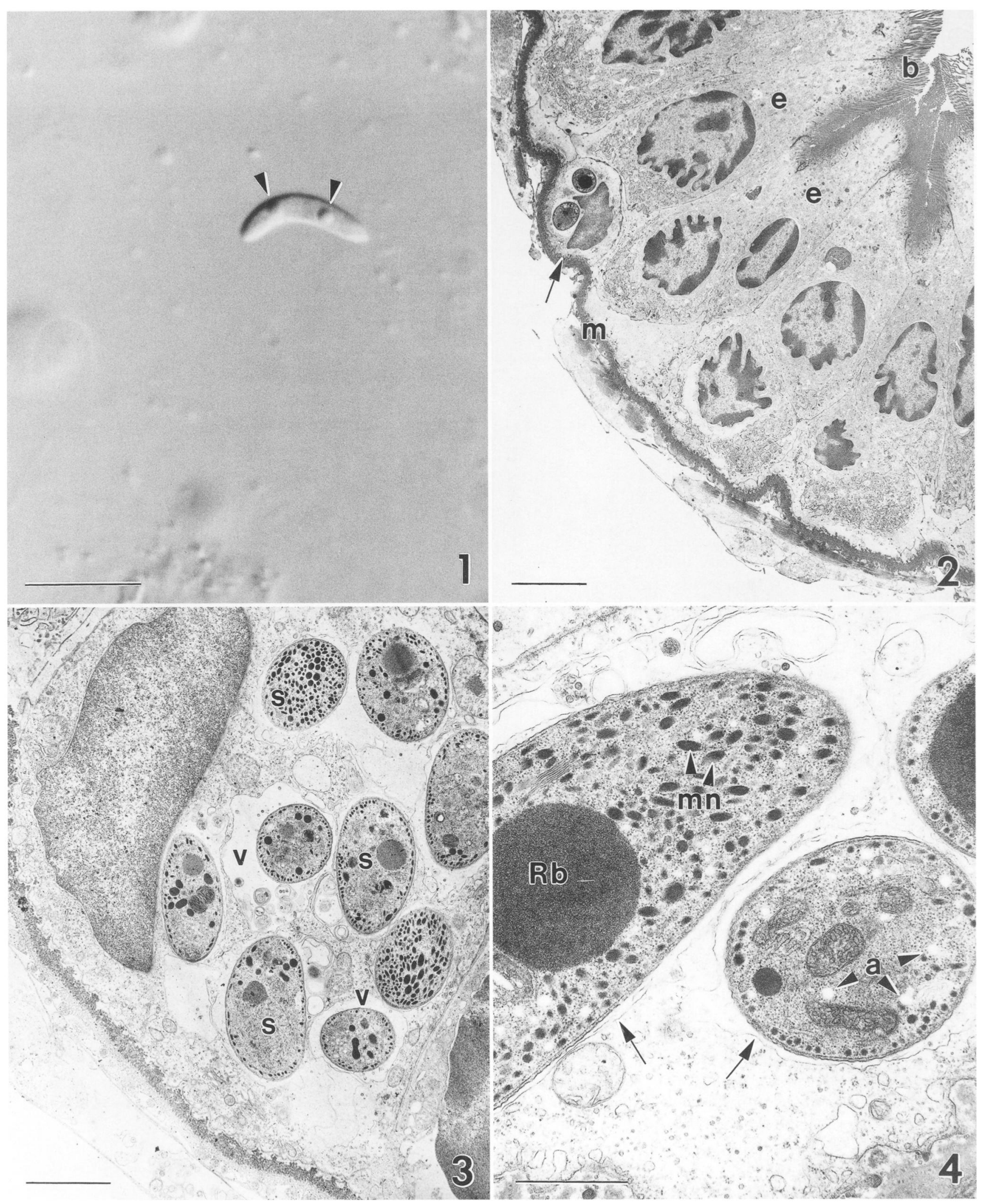

FIGURES 1-4. Infective sporozoites of Calyptospora funduli in the daggerblade grass shrimp, Palaemonetes pugio, 7 days after being fed liver containing sporulated oocysts. (1) Infective sporozoite from intestinal contents. Note the two prominent refractile bodies (arrowheads). Bar $=15$ $\mu \mathrm{m}$. (2) Low-magnification electron micrograph (EM) showing cross-sections of two sporozoites in basal cell (arrow) of intestinal mucosa. Note brush border (b), columnar epithelial cells (e), and basement membrane (m). Bar $=10 \mu \mathrm{m}$. (3) Higher magnification of infected basal cell 
fin. Tissue impressions were prepared by touching the cut surface of the liver and spleen to glass microscope slides and allowing them to air dry. Blood smears and tissue impressions were stained with American Scientific Products Camco Quik Stain (available from Sigma, St. Louis, Missouri) or Fisher Scientific Giemsa stain (Pittsburgh, Pennsylvania). Smears stained with Camco Quik Stain were dipped in stain for $10 \mathrm{sec}$ then in distilled water for $20 \mathrm{sec}$. Smears stained with Fisher Scientific Giemsa stain were fixed in methanol for 5-10 min, stained in a working solution of the stain for $25 \mathrm{~min}$, then dipped in distilled water. The 2 remaining fish were examined 20 days PI to verify infection with $C$. funduli.

\section{RESULTS}

Light microscopic examination of squash preparations of intestine from experimentally infected grass shrimp 7 days PI showed large numbers of nonmotile sporozoites. The sporozoite had a distinct nucleus near the center of the body, with 2 relatively large refractile bodies, 1 being situated anterior to and the other posterior to the nucleus (Fig. 1). Sporozoites were suspended in intestinal contents and occurred alone or appeared to be situated in nests between intestinal cells. Sporozoites could not be seen in intestinal epithelial cells of the grass shrimp or in any other cell types by this method.

Semithin cross-sections of grass shrimp intestine revealed sporozoite-like stages in the cytoplasm of the basal cells, which are located proximal to the nuclei of the simple columnar epithelial cells (Fig. 2). Cross-sections of many infected cells exhibited 1-5 sporozoite-like stages within a single cell, but a few had up to 13 per cell (Fig. 3). Ultrastructurally, the intracellular stages were identified as sporozoites, and they contained the characteristic cytoplasmic organelles. These structures included refractile bodies, a pellicle, micronemes, rhoptries, amylopectin granules, mitochondria, Golgi complexes, ribosomes, and a nucleus (Fig. 4). Additionally, individual sporozoites appeared to be situated in single membrane-bound vesicles rather than within a single parasitophorous vacuole (Figs. 3, 4). No evidence of replication was evident.

Sporozoites were found in the peripheral blood from 1 of 2 specimens of $F$. similis examined at $4 \mathrm{hr} \mathrm{PI}$, and all sporozoites contained 2 distinctive refractile bodies (Figs. 5, 6). No sporozoite was observed in the peripheral blood of the other 16 killifish examined at the later time intervals. Additionally, eosinophilic inclusions resembling coccidian trophozoites and meronts were seen in hepatocytes from several killifish at 48, 72, and 96 hr PI. Sporozoites or sporozoitelike stages were not found in the intestinal lumen, mucosa, or submucosa nor in tissue impressions of liver and spleen of $F$. similis examined anywhere from 4 to $96 \mathrm{hr}$ after ingesting experimentally infected grass shrimp. The 2 positive control fish had infections with developing oocysts at 20 days PI.

\section{DISCUSSION}

Using transmission electron microscopy, Fournie and Overstreet (1983) noted that in 1 instance, a few sporozoites were seen within a degenerated cell of a $P$. pugio intestine. This was

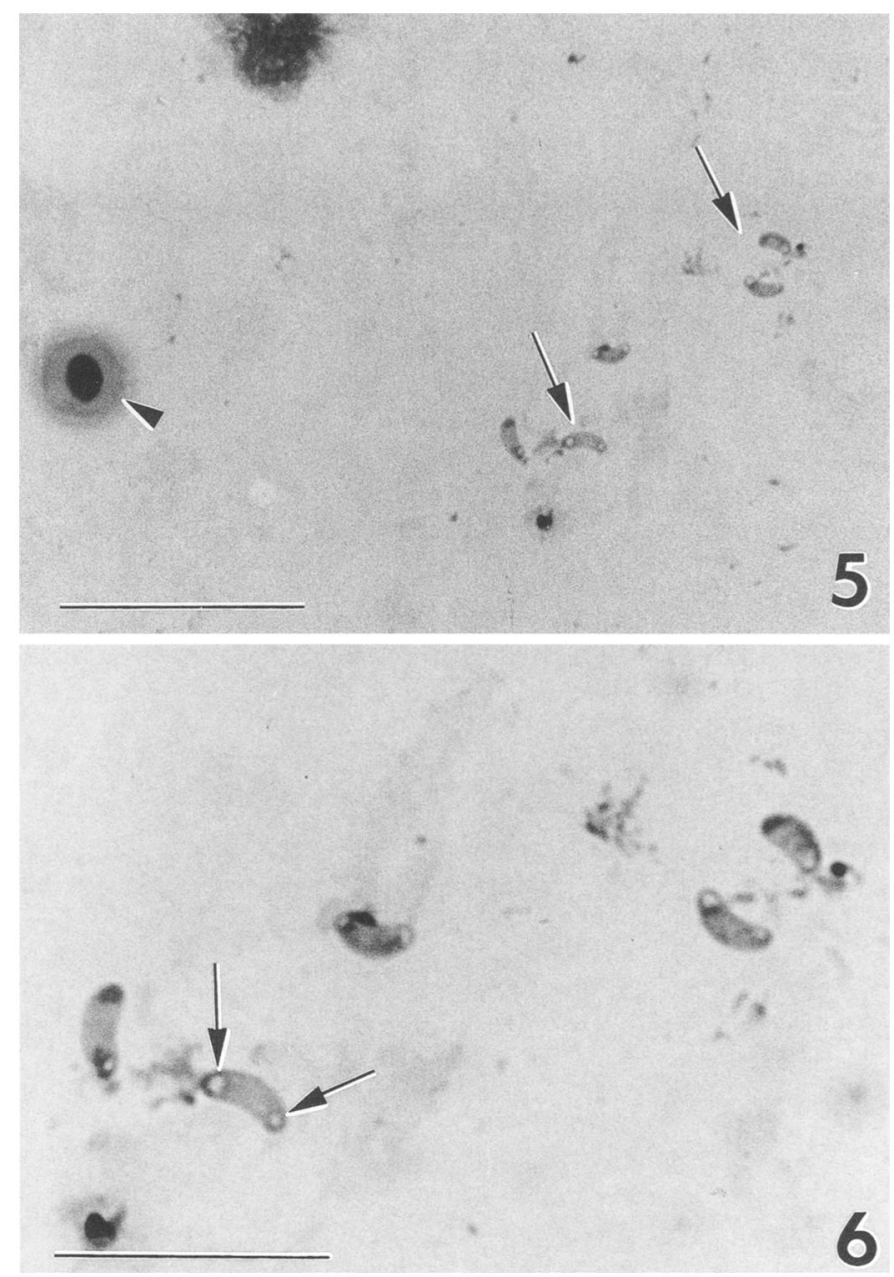

FIGURES 5, 6. Peripheral blood smears from experimentally infected longnose killifish (Fundulus similis) $4 \mathrm{hr}$ PI; Giemsa stain. (5) Sporozoites of $C$. funduli (arrows). Note erythrocyte (arrowhead). Bar $=100$ $\mu \mathrm{m}$. (6) Higher magnification of sporozoites showing distinctive refractile bodies (arrows). Bar $=50 \mu \mathrm{m}$.

the only evidence provided that indicated that sporozoites might infect shrimp intracellularly as previously suggested (Landau et al., 1975; Dyková and Lom, 1981; Upton and Duszynski, 1982). Whereas Fournie and Overstreet (1983) saw no indication of division of the parasite in the grass shrimp in fresh squash preparations, the present study clearly demonstrates that sporozoites can enter host cells. However, based on the lack of reproducing stages, intracellular asexual multiplication appears unlikely in the grass shrimp intermediate host. The fact that infected cells exhibited from 1 to 13 sporozoites within a basal cell and each of those occurred within its own parasitophorous vacuole provides evidence for multiple penetrations rather than for a form of asexual multiplication. Because the grass shrimp were not laboratory reared, some of the many sporozoites seen

$\leftarrow$

showing nine sporozoites (s), each within a distinct membrane-bound parasitophorous vacuole (v). Bar $=2 \mu \mathrm{m}$. (4) Higher magnification EM showing characteristic features of sporozoites. Note refractile body (Rb), micronemes (mn), amylopectin granules (a), and membrane (arrows) surrounding individual sporozoites. Bar $=1 \mu \mathrm{m}$. 
by electron microscopy could have been present from a natural infection. Sporozoites can apparently survive in the grass shrimp at least 201 days (Fournie and Overstreet, 1983).

The ultrastructure of the sporozoite of $C$. funduli within basal cells of the grass shrimp intestine was consistent with fine structural features of other piscine coccidian sporozoites (Paterson and Desser, 1984; Morrison and Poynton, 1989; Steinhagen, 1991) and eimerian-type sporozoites in general (Chobotar and Scholtyseck, 1982). All have the distinctive refractile bodies, micronemes, rhoptries, and amylopectin granules. Sporozoites of G. carpelli invaded intestinal epithelial cells, and sporozoites of $G$. subepithelialis were found in epithelial and phagocytic cells of the alimentary canal of tubificid oligochaetes (Steinhagen, 1991). In both cases, the sporozoites occurred singly in membrane-bound parasitophorous vacuoles. The infection of $C$. funduli is different because single or multiple sporozoites, which undergo development, usually occurred within individual membrane-bound vesicles in basal cells of the grass shrimp intestine.

Once an infected grass shrimp is ingested by a fish host, infective sporozoites of $C$. funduli apparently gain access to the fish's hepatocytes through its circulatory system, as evidenced by the occurrence of sporozoites in the peripheral blood of killifish $4 \mathrm{hr}$ after ingesting infected grass shrimp. A few authors (Odense and Logan, 1976; Paterson and Desser, 1982) have suggested that sporozoites of some extraintestinal forms reach their target organs through the circulatory system. Odense and Logan (1976) reported sporocysts of G. gadi within and around a major hepatic vein of the haddock but no sporozoites in peripheral blood smears. Paterson and Desser (1982) reported finding "tiny apicomplexan-like meronts" in the vascular endothelium of the liver and swim bladder of common shiners infected with $G$. deguistii. Even though sporozoites were not seen in the intestinal mucosa or submucosa of exposed $F$. similis, they presumably penetrate the intestinal mucosal epithelium, enter small blood vessels in the lamina propria, and subsequently pass through the hepatic portal system, either directly or possibly within a migratory host cell. The sporozoites observed in a peripheral blood smear obtained from the severed caudal peduncle of 1 fish at $4 \mathrm{hr}$ PI indicated that they reached the liver through the circulatory system. This route would account for the short time necessary for the parasite to reach the liver, and it would also explain the reported but rarely observed extrahepatic sites (Solangi and Overstreet, 1980). Hawkins et al. (1984) have demonstrated that the parasite reaches the liver quickly because the first of 2 generations of merozoites are well developed by day $4 \mathrm{PI}$ in $F$. similis.

The eosinophilic inclusions seen in hepatocytes of killifish at 48 to $96 \mathrm{hr}$ PI resembled eimerian trophozoites and meronts. This finding supports the hypothesis that the sporozoites reach the liver of killifish in a short period of time, which in turn provides further support for the sporozoites using the circulatory system to reach the liver. These inclusions morphologically resemble the eosinophilic bodies illustrated by Upton and Duszynski (1982) from experimentally infected $F$. heteroclitus at 5 and 6 days PI. Sporozoites of $C$. funduli may require more time to become established in the liver of $F$. heteroclitus than in the liver of $F$. similis.

Even though Molnár (1995) considered the grass shrimp to be a paratenic host for $C$. funduli, in which the sporozoites do not undergo development, Solangi and Overstreet (1980), Fournie and Overstreet (1983), and the present study clearly show that the grass shrimp serves as a necessary intermediate host in the life cycle of $C$. funduli, rather than a paratenic host in which the parasite undergoes no further development. Goussia carpelli and probably $G$. subepithelialis, in studies by Steinhagen (1991) and Steinhagen and Körting $(1988,1990)$ dealing with those intestinal coccidians and 2 oligochaete paratenic hosts, differ from ours because no development was noted and the oligochaete worm was not necessary to complete the life cycle. Whether sporozoites of $C$. funduli resulted from asexual multiplication or represent maturing individuals is not known. Nevertheless, without a developmental period of about 5 days in the grass shrimp, the sporozoite is not infective to killifishes (Fournie and Overstreet, 1983). Consequently, the crustacean invertebrate host is necessary to complete the life cycle.

Lom and Dyková (1992) stated that the definition of the Eimeriidae by Levine (1985) adequately covers Calyptospora. Levine's definition included those coccidians that were homoxenous or at least without asexual multiplication in the nondefinitive host. Those authors indicated that they preferred to leave Calyptospora in the Eimeriidae unless asexual multiplication can be demonstrated in the intermediate host. However, because $C$. funduli uses the crustacean as more than a paratenic host and has distinguishing morphological structures, features that clearly distinguish related coccidians from the "typical" eimeriids, we believe that $C$. funduli belongs in the Calyptosporidae as described by Overstreet et al. (1984), rather than in Eimeriidae. Even though life cycles of the other species in the genus Calyptospora have not been demonstrated experimentally, it is likely that they are similar. Subsequently, Levine (1988) did accept the Calyptosporidae in his revision of the Apicomplexa.

\section{ACKNOWLEDGMENTS}

We thank Patrice Mason for printing the figures and Valerie Coseo for typing the manuscript. Funded in part from NOAA, NMFS award NA86FL0476, and USDA CSREES award 9838808-6019. This paper is contribution number 1077 of the U.S. Environmental Protection Agency, National Health and Environmental Effects Research Laboratory, Gulf Ecology Division, Gulf Breeze, Florida 32561.

\section{LITERATURE CITED}

Сhobotar, B., And E. Scholtyseck. 1982. Ultrastructure. In The biology of the coccidia, P. L. Long (ed.). Edward Arnold Press, London, U.K., p. 101-165.

Dyková, I., AND J. Lom. 1981. Fish coccidia: Critical notes on life cycles, classification and pathogenicity. Journal of Fish Diseases 4: 487-505.

Fournie, J. W., AND R. M. OverstreEt. 1983. True intermediate hosts for Eimeria funduli (Apicomplexa) from estuarine fishes. Journal of Protozoology 30: 672-675.

, AND -1993 . Host specificity of Calyptospora funduli (Apicomplexa:Calyptosporidae) in atheriniform fishes. Journal of Parasitology 79: 720-727.

Hawkins, W. E., J. W. Fournie, and R. M. Overstreet. 1984. Intrahepatic stages of Eimeria funduli (Protista: Apicomplexa) in the longnose killifish, Fundulus similis. Transactions of the American Microscopical Society 103: $185-194$.

Hayat, M. A. 1981. Principles and techniques of electron microscopy: 
Biological applications, vol. 1, 2nd ed. University Park Press, Baltimore, Maryland, $522 \mathrm{p}$.

Landau, I., M. Marteau, Y. Golvan, A. G. Chabaud, and Y. BouLARD. 1975. Hétéroxénie chez les coccidies intestinales des poissons. Comptes Rendus Hebdomadaires des Séances de l'Académie des Sciences, Paris, Série D 281: 1721-1723.

Levine, N. D. 1985. Phylum II. Apicomplexa Levine, 1970. In An illustrated guide to the Protozoa, J. J. Lee, S. H. Hunter, and E. C. Bovee (eds.). Society of Protozoologists, Lawrence, Kansas, p. 322-374.

. 1988. The protozoan phylum Apicomplexa, vol. I. CRC Press, Boca Raton, Florida, 203 p.

Lom, J., AND I. DykovÁ. 1992. Protozoan parasites of fishes. Developments in Aquaculture and Fisheries Science, 26. Elsevier Science Publishers B.V., Amsterdam, The Netherlands, 315 p.

MolnÁr, K. 1995. Phylum Apicomplexa. In Fish diseases and disorders, vol. 1, protozoan and metazoan infections, P. T. K. Woo (ed.). CAB International, University Press, Cambridge, U.K., p. 263-288.

Morrison, C. M., AND S. L. Poynton. 1989. A new species of Goussia (Apicomplexa, Coccidia) in the kidney tubules of the cod, Gadus morhua L. Journal of Fish Diseases 12: 533-560.

Odense, P. H., AND V. H. LOGAN. 1976. Prevalence and morphology of Eimeria gadi (Feibiger, 1913) in the haddock. Journal of Protozoology 23: 564-571.

OverstreEt, R. M. 1981. Species of Eimeria in nonepithelial sites. Journal of Protozoology 28:258-260.
, W. E. Hawkins, AND J. W. Fournie. 1984. The coccidian genus Calyptospora n.g. and family Calyptosporidae n. fam. (Apicomplexa), with members infecting primarily fishes. Journal of Protozoology 31: 332-339.

Paterson, W. B., AND S. S. Desser. 1982. The biology of two Eimeria species (Protista: Apicomplexa) in their mutual fish hosts in Ontario. Canadian Journal of Zoology 60: 764-775.

, AND - 1984. Ultrastructural observations on fertilization and sporulation in Goussia iroquoina (Molnar and Fernando, 1974) in experimentally infected fathead minnows (Pimephales promelas, Cyprinidae). Journal of Parasitology 70: 703-711.

SolangI, M. A., AND R. M. OverstreET. 1980. Biology and pathogenesis of the coccidium Eimeria funduli infecting killifishes. Journal of Parasitology 66: 513-526.

STEINHAGEN, D. 1991. Ultrastructural observations on sporozoite stages of piscine coccidia: Goussia carpelli and G. subepithelialis from the intestine of tubificid oligochaetes. Diseases of Aquatic Organisms 10: 121-125.

- AND W. KÖRTING. 1988. Experimental transmission of Goussia carpelli (Leger \& Stankovitch, 1921; Protista:Apicomplexa) to common carp, Cyprinus carpio L. Bulletin of the European Association of Fish Pathologists 8: 112-113.

, AND 1990 . The role of tubificid oligochaetes in the transmission of Goussia carpelli. Journal of Parasitology 76: 104107.

Upton, S. J., AND D. W. DUSZYNSKI. 1982. Development of Eimeria funduli in Fundulus heteroclitus. Journal of Protozoology 29: 66-71. 